a merchant stranger living in Philpot Lane in the City. Probably Sherard and Brooke were only messengers, or currers, as they would have been called in earlier days, who conveyed the mail from London to the port of despatch, but De Quester, if not at first, certainly in the course of time, obtained control of the post and seems to have made it efficient. But he too had his troubles, and among them was the difficulty, which he shared with others of King James's servants, in getting paid for the services which he rendered to the State. Chamberlain, writing to Dudley Carleton in January 1615, says 'Eren poor De Quester, the postmaster, runs ap and down for paymentrof 600l. dae to him for postages." "This amount no doubt represents arrears covering a long period. Several of $\mathrm{De}$ Quester's accounts for postages, beginning in January 1608, are preserved in the Public Record Office. They are made out very neatly, and contain particulars of each packet received from the Continent or despatched thither, and in the case of packets received the account shows how long it has taken on the journey, to whom it was addressed, and how it was delivered to the addressee. From the earliest of these accounts it seems that the average time occupied in conveying a letter from Brussels to London in 1608 was a little over nine days. ${ }^{13}$ The approximate time taken in the transmission of correspondence between the two cities is now eight hours and a half. In 1619, King James granted a patent to De Quester and his son for the control of the foreign post, and this was the cause of much litigation between Lord Stanhope, the master of the posta, and De Quester and his successors."

J. A. J. HousDEN.

\title{
Cromwell's Instructions to Colonel Lockhart in 1656.
}

Tye instructions usually given to English ambassadors during the Commonwealth were simple end.. direct. They are a contrast to the fall and elaborate instructions given to French ambassadors at the same period, which often became lengthy treatises on the past relations of France with particular powers and on the present state of politics in the country to which the ambassador was accredited. The collection published under the auspices of the French ministry of foreign affairs shows this. ${ }^{1}$ Bat though similar English instructions are of less interest and of less general value to historians, they throw considerable light on the develop-

Is State Papers, Dom., Jamea I, Inx. 10.1 "Ibid. Irrii. 35.

$14 \mathrm{H}$. Joyce, History of the Post Office, ch. ii.

' Recusil des Instructions donneles aux Ambassadeurs de France dopuis les Traites do Westphalie jufqu'd la Rdoolution frangaise. 
ment of English foreign policy, and a small collection of them, illustrating our relations with the more important foreign states, would be of some interest. Unluckily only a few of them are in print. For the period of the Commonmealth and the Protectorate some half-dozen may be found published in the Thurloe Papers-for instance, the instructions to Lord Lisle on his proposed mission to Sweden in 1659.2

As specimens of the instructions given by the Protector to his diplomatic agents we have those to Richard Bradshaw for his abortive mission to the tsar (May 1657), to Colonel Jephson when he was sent to negotiate with the king of Sweden (22 August 1657), to Philip Meadowe when he was employed to mediate between Sweden and Poland (9 April 1658), and Downing's instructions in November 1658, when Richard Cromwell's government was attempting to patch up a peace between Portugal and the States General." But the most important fact in Cromwell's foreign policy was his alliance with France, and the instructions given to the ambassador who negotiated that alliance have not hitherto been printed. On 29 February 1656 the council of atate advised the Protector to send Colonel William Lockhart as resident to France." His credentials are dated about 9 April $1656 .^{5}$ His instractions, printed below, should no doubt also be dated in that month. They are to be found in the Record Office in State Papers, France, vol. 113. Some additional instructions sent later are printed in Thurloe, $\nabla .41$, and should be compared with these, which they serve to supplement. The contractions in the manuscript of the instructions bave been extended. C. H. FIRTH.

Instructions unto collonel William Lockart sent unto the french king.

1. As soone as you have received these instructions, you shall forthwith repeir on board the ship appointed for your transportacion; and hasten to such place in France, where the hing shall bee.

2. And being admitted to your first andience, you shall lett the king know, that it haveing pleased God to blesse the conncell and endeavours of both partyes in the late Treatyes, that a firme pesce and freindship is setled, and establisht between these two nacions, I have thought fitt to send you unto his majestie to assure him, that I ahall not only most inviolately keep, and observe the said Treaty of peace, but shall be ready to cultivate and improve the present good intelligence between us, to a forther encrease of amity and good will, and doubt not of the same good inclinacions, and disposicions in his majestie, with such further expressions of freindship as you shall judge fitt and necessary.

8. After your publique audience you shall desire private conference with the Cardinal, and haveing delivered my letter to him, saluted him

2 Tharloe, i. 227. . $\quad$ Tbid. vi. 278, 478, rii. 68, 617.

- Cal. S. P., Dom., 1655-6, p. 204.

- Masson, Life of Milton, v. 251 ; Hamilton, Milton Papers, pp. $9,10$. 
in my name, and assured him of my hearty effeccion towards him and his interest, you shall lett him know that I doe understand it to be the true-interest of both these nacions, and for the common good of our neighbours and allies, not only to live in freindship and to bold a good correspondence and intelligence with each other, but to come to a nearer union, and more intimate allyance than is setled and establisht by the late Treaty.

4. That I have allwayes shewed a propensity thereunto, and have at all times with much willingnesse [recoived] any proposicions and tenders of that nature, as thinkeing that they had a mutuall convenienoy in them, and to be very agreable to the intereste of both.

5. And at this time in a more especiall manner, the affayres of both seem to me to be such (they haveing now one common enemy) that doe render a confident communicacion therein very necessary, and give oportunity to the two states of being very useful to each other, for the carrying on their common interesta.

6. And further onderstanding by Monsier de Bourdesux at his departure hence, as also by letters which he writt hither after he had given an account of his negotiacion to the king and cardinall, and was informed of their intencion, that they had, at that court, the same sense of affaires, and were disposed to come into further termes of amity, I have been willing to send you imediately from my selfe to speak and conferre with the cardinal in all confidence and freedome, concerning these things ; and as well to open my mind and intencions therein unto him, as to receive his, and to assure him by one whom he may be satisfyed I perfectly trust, that in case he judgeth it of advantage to himselfe and France to joyne intimately with me and this comonwealth, he shall find upon experience that there is no person in Europe who will be a more certaine and constant freind to him and the affayres of France then my selfe.

7. And upon this occession, you may insinuste, that I have taken France for a freind, not out of necessitie, but choice, that it cannot be anknowne to the cardinall what tenders have been made by Spaine to have turned the armes of this state another way, nor what my principles are which lead me to a closure with France, rather then with Spaine; I haveing often declared them to the French Ambassador here, viz. that the one gives libertie of conscience to the prafessors of the protestant. religion, and the other persecuteing it with losse of life and estate, that therefore the friendahip is like to be constant, and lasteing on my part, hareing in the contracting thereof, not only satisfyed the interest of this state, but parsued my owne principles and conscience, and if the amity be as sincere and as well grounded in the king, I for my part should not donbt, but (through the blessing of God) both sides might in a very short time receive the happy effects of so hearty a conjunction.

8. And in pursuance hereof, you shall either at the first, or any other conference, as you find it most proper and convenient, acquaint him, that I doo fully agree with what was proponnded by the said Franch Ambassador at the time of his departure hence, that now is the time for both sides to consider and take councel, concerning Spaine the common

- The treaty of 24 October-8 . November 1655. 
enemy of both States, whether, and how one confederate may be asefull to the other in eny designe against him.

9. And to that purpose, you shall lett him know that before I would take any resolution, or purpose any thing in pertionlar to France upon this subject, I thought it necessary to send you thither to communicate with the cardinall therein, thst I might further onderstand his mind, and know what advise he would give me in a matter so much importing the interest of both.

10. In case the cardinall shall manifast a readinesse herennto, and be of opinion that any designe be to be undertaken against Bpaine, by joynt councel and forces, and propound anything in particuler (which you shall endeavour by fitting arguments to draw from him), you have power to conferre with him, of the equality, matuall conveniency, and reasonablenesse of suoh proposicions, and you are to transmitt what shall be offered to you on that subject, to us, by an expresse, whereupon you shall have further instructions how to proceed; in the mean time, you may lett him know that other things being agreed, wee shall be willing to consent, that neither confedarate shall make any peace or trace with Speine, withoutt the consent of the other.

11. You shall take all oportanityes to penetrate into the connsells as well of the cardinal as other ministers of state, in' reference to this Commonwealth, and how they atand inclined to the particulers aforesaid, as also what the disposicions of that Court is, as to a peace with Bpaine, and whether there bee any advances made therein, and you shall dureing your residence in France, use all possible endeavours by such proper mediums as you shall judge fitt to hinder and obstruct the aforessid peace.

12. You shall with the first oportanity represent to the cardinal, and as it shall be necessary to the king, the sadd and miserable condicion of the poor Protestants of Piemont, in the Dominions of the Duke of Savoy, many of their brethren haveing been massacred in a most cruel manner, and those who doe servive are like to be destroyed, either through the hard termes of peace, which they have been perswaded to take, or by not performance, or rather violacion, of those condicions which were given them.

18. That when any addresseg are made to the Duke on their behalf, his answer is, that he hath wholly referred that businesse to the French king, and therefore you shall further represent, that seing this matter is come into the king's hands, and thet it is in his power, either to destroy or preserve these poor people, and deliver them from that death, which they are now in, or dayly subjected to ; wee cannot but expect it from that freindship and amity, which is between us, and from those principles which France hath allwayes professed towards the Proteatants in their owne dominions, that he will take such effectuall course, that the Duke of Bavoy may not only make good and performe the late Treaty, but cause it to be amended in such manner, as that those people may be secured in their lives, estates, consciences, and ancient priviledges, whereby the king will not only doe that which is just and pleasing to God and very acceptable to all his neighbours of the same proffession, but oblige those men to him, and further encourage his owne protestant subjects to continue their fidelity and services to his Majestie. 
746 CROMWELI'S INSTRUCTIONS TO LOCKHART Oct.

14. And you shall presse the matter of the foregoing article with such other arguments as you shall judge proper, and with all manner of instances insist thereupon, until you shall procure somewhat to be done with effect for those poor people; and therein you shall correspond with Mr. Moreland, our commissioner extraordinary now at Geneva, who shall have directions to give you from time to time a perfect account of their condicion, and what will be fitt to bee insisted apon in particuler on their behalf.

15. And as you shall understand the condicion and institacion of affairs to be in Swisserland, you shall accordingly endeavour to dispose the court of France towards the protestant cantons.

16. You shall from time [to time] sasist the English merchants tradeing into France, in all such their occasions as shall require your helpe and countenance at the court; and in case any of the Articles of the late Treaty be not performed by the king of France, or any of his subjecte, you shall represent the same where it shall be necessary for redresse therein.

17. You shall hold a good correspondence with the ambassador and publique ministers of other Princes and States in amity with us resideing in the court of France.

18. You shall give frequent accounts of your negociacions unto us, that you may receive such further instructions as shall be necessary. 
ment of English foreign policy, and a small collection of them, illustrating our relations with the more important foreign states, would be of some interest. Unluckily only a few of them are in print. For the period of the Commonmealth and the Protectorate some half-dozen may be found published in the Thurloe Papers-for instance, the instructions to Lord Lisle on his proposed mission to Sweden in 1659.2

As specimens of the instructions given by the Protector to his diplomatic agents we have those to Richard Bradshaw for his abortive mission to the tsar (May 1657), to Colonel Jephson when he was sent to negotiate with the king of Sweden (22 August 1657), to Philip Meadowe when he was employed to mediate between Sweden and Poland (9 April 1658), and Downing's instructions in November 1658, when Richard Cromwell's government was attempting to patch up a peace between Portugal and the States General." But the most important fact in Cromwell's foreign policy was his alliance with France, and the instructions given to the ambassador who negotiated that alliance have not hitherto been printed. On 29 February 1656 the council of atate advised the Protector to send Colonel William Lockhart as resident to France." His credentials are dated about 9 April $1656 .^{5}$ His instractions, printed below, should no doubt also be dated in that month. They are to be found in the Record Office in State Papers, France, vol. 113. Some additional instructions sent later are printed in Thurloe, $\nabla .41$, and should be compared with these, which they serve to supplement. The contractions in the manuscript of the instructions bave been extended. C. H. FIRTH.

Instructions unto collonel William Lockart sent unto the french king.

1. As soone as you have received these instructions, you shall forthwith repeir on board the ship appointed for your transportacion; and hasten to such place in France, where the hing shall bee.

2. And being admitted to your first andience, you shall lett the king know, that it haveing pleased God to blesse the conncell and endeavours of both partyes in the late Treatyes, that a firme pesce and freindship is setled, and establisht between these two nacions, I have thought fitt to send you unto his majestie to assure him, that I ahall not only most inviolately keep, and observe the said Treaty of peace, but shall be ready to cultivate and improve the present good intelligence between us, to a forther encrease of amity and good will, and doubt not of the same good inclinacions, and disposicions in his majestie, with such further expressions of freindship as you shall judge fitt and necessary.

8. After your publique audience you shall desire private conference with the Cardinal, and haveing delivered my letter to him, saluted him

2 Tharloe, i. 227. . $\quad$ Tbid. vi. 278, 478, rii. 68, 617.

- Cal. S. P., Dom., 1655-6, p. 204.

- Masson, Life of Milton, v. 251 ; Hamilton, Milton Papers, pp. $9,10$. 